\title{
Real-Time PCR Quantification of Bovine Lactase mRNA: Localization in the Gastrointestinal Tract of Milk-Fed Calves*
}

\author{
E. C. Ontsouka, ${ }^{1}$ B. Korczak, ${ }^{2}$ H. M. Hammon, ${ }^{1,} \dagger$ and J. W. Blum ${ }^{1}$ \\ Division of Animal Nutrition and Physiology, \\ Institute of Animal Genetics, Nutrition, and Housing, and \\ ${ }^{2}$ Institute of Veterinary Bacteriology, Vetsuisse Faculty \\ University of Berne, $\mathrm{CH}-3012$ Berne, Switzerland
}

\begin{abstract}
Lactase is a disaccharidase that is present in the brush-border membrane of the small intestine, hydrolyzes lactose to glucose and galactose, and is therefore important in milk-fed animals. Assays based on quantitative real-time reverse transcription-polymerase chain reaction (RT-PCR) in the bovine species have not yet been described. Therefore, we have developed an RT-PCR assay for the quantification of lactase mRNA levels and have tested its suitability in the bovine gastrointestinal tract of seven 5-d-old milk-fed calves. Primers for RT-PCR amplification of bovine lactase mRNA were designed in the $100 \%$ identical regions of species (rats, rabbits, humans) from which lactase sequences were available. Lactase mRNA was expressed relative to mean levels of 4 housekeeping genes (glyceraldehyde-3-phosphate dehydrogenase, $\beta$ actin, ubiquitin, and 18S). The presence of lactase mRNA along the entire gastrointestinal tract was evaluated in samples that consisted of whole gut walls (mucosa plus submucosa). Furthermore, mRNA levels of lactase were measured in fractionized layers of jejunal and ileal mucosa (mainly containing villus tips or crypts) and ileal lamina propria (mainly containing Peyer's patches). Agarose gel electrophoresis of the lactase PCR product revealed a single band that corresponded to the single-amplified product as predicted by the melting curve analysis of the PCR. The amplified partial-bovine lactase sequence showed $87 \%$ similarity with human and rabbit sequences and $82 \%$ similarity with the rat sequence. Lactase mRNA was present in whole walls (consisting of mucosa and
\end{abstract}

Received April 13, 2004.

Accepted June 16, 2004.

Corresponding author: J. W. Blum; e-mail: juerg.blum@itz. unibe.ch.

*This study was in part supported by Swiss National Science Foundation (grant \# 32-56823.99).

$\dagger$ Present address: Research Institute for Biology of Farm Animals, Nutrition Physiology (Oskar Kellner Institute), Wilhelm-Stah-Allee, D-18196 Dummerstorf, Germany. submucosa) of the entire small intestine, but was absent in esophagus, rumen, fundus, pylorus, and colon. Furthermore, lactase mRNA was detected in fractionized villus and crypt layers of jejunum and ileum, but levels were higher in the jejunum in villus than in crypt fractions. No lactase mRNA was detectable in the lamina propria fraction of the ileum containing mainly Peyer's patches. In conclusion, the developed RT-PCR method allows study of lactase mRNA levels. (Key words: gastrointestinal tract, mRNA, lactase, calf)

Abbreviation key: BrdU = 5'-bromo-2-deoxyuridine, $\mathbf{C P}=$ crossing point, GAPDH = glyceraldehyde-3phosphate dehydrogenase, HKG = housekeeping gene, $\mathbf{L P}=$ lamina propria, $\mathbf{P P}=$ Peyer's patches, $\mathbf{R T}-\mathbf{P C R}=$ reverse transcription-polymerase chain reaction, $\mathbf{S I}=$ small intestine.

\section{INTRODUCTION}

Lactase-phlorizin hydrolase-or simply lactase-is an enzyme localized in the brush-border membrane of the small intestine (SI) and is thus a marker of intestinal epithelial differentiation. Lactase hydrolyzes lactose to glucose and galactose. It is therefore important for energy use in preruminant calves and especially for veal calves that ingest high amounts of lactose with milk and milk replacers for several months. Lactase mRNA is already present during the fetal period and lactase activity increases markedly during final fetal stages (Buller et al., 1990; Sangild et al., 2000). More diarrheas due to insufficient lactose digestion can be seen in preterm than in fullterm neonates because lactase activity may not be fully developed (Kien et al., 1996; Shulman et al., 1998). After birth, levels of mRNA and lactase activity depend on ontogenetic state, intestinal sites, and developmental stages of enterocytes, and are influenced by nutrition (Freund et al., 1995; Dudley et al., 1996, 1998). Lactase activity is high at birth and then declines, especially after weaning (Duluc et al., 1993; Tang et al., 1999; Bittrich et al., 2004). Colostrum intake at birth stimulates lac- 
tase activity (Dudley et al., 1996; Zhang et al., 1997; Jost et al., 1998). In rats, the expression of lactase mRNA levels and lactase activities were positively correlated (Buller et al., 1990). If only small amounts of material are available, lactase activities may not be measurable. If so, it would be preferable if mRNA could be analyzed, especially if such a highly sensitive method as the real-time reverse transcription-polymerase chain reaction (RT-PCR) could be applied. To the best of our knowledge, there are no published studies on quantitative RT-PCR of lactase in bovine. Based on that, we have developed and validated an RT-PCR assay to measure lactase mRNA expression. The established assay was tested by investigating the localization of mRNA within the gastrointestinal tract of 5-d-old milk-fed calves.

\section{MATERIALS AND METHODS}

\section{Animals and Experimental Design}

The experimental procedures were in accordance with the current Swiss Law on Animal Protection and were approved by the Cantonal Committee for Animal Experimentation of the Canton of Freiburg (GrangesPaccot, Switzerland). The planned procedures were supervised by the Swiss Federal Veterinary Office (Liebefeld-Berne).

Single-born calves from different dairy breeds (Simmental $\times$ Red Holstein, Holstein-Friesian, and Brown Swiss), originating from the Swiss Federal Research Station for Animal Production, Posieux, were used. Calves $(n=7)$ were spontaneously born after normal lengths of pregnancy ( $290 \pm 2 \mathrm{~d})$ and were euthanized on $\mathrm{d} 5$ of life. One hour before euthanasia, calves were intravenously injected with $500 \mathrm{mg}$ of 5'-bromo-2deoxyuridine (BrdU) to label proliferating cells, as described by Blättler et al. (2001).

Calves were held on straw in individual boxes for 4 $\mathrm{d}$. They were fed with pooled colostrum, derived from about 70 dairy cows, of milkings 1,3 , and 5 (d 1, 2, and 3 of lactation, respectively) on d 1,2, and 3 of life, respectively. On d 4, all calves received a milk replacer. Amounts of colostrum were $6 \%$ of BW on d 1,8\% of BW on $\mathrm{d} 2$, and $10 \%$ of BW from d 3 . The colostrum fed to calves on d 1 contained $240 \mathrm{~g}$ of DM/ $\mathrm{kg}$ and per $\mathrm{kg} \mathrm{DM}$ contained $24.9 \mathrm{MJ}$ of gross energy, $555 \mathrm{~g}$ of $\mathrm{CP}, 265 \mathrm{~g}$ of crude fat, $104 \mathrm{~g}$ of nitrogen-free extract (mainly lactose), and $75 \mathrm{~g}$ of crude ash. The colostrum fed to calves on d 2 and 3 contained $160 \mathrm{~g}$ and $154 \mathrm{~g}$ of DM and per kg DM contained 24.5 and 24.6 MJ of gross energy, 390 and $326 \mathrm{~g}$ of CP, 290 and $320 \mathrm{~g}$ of crude fat, 263 and $297 \mathrm{~g}$ of nitrogen-free extract, and 63 and $58 \mathrm{~g}$ of crude ash, respectively.
To protect against infections, calves were injected with $20 \mathrm{~mL}$ of an immunoglobulin preparation (Gammaserin, $100 \mathrm{~g}$ immunoglobulin G/L; Gräub AG, Berne, Switzerland) immediately after birth. Between d 2 and 5, they were subcutaneously injected with antibiotics once daily $(2.5 \mathrm{mg} / \mathrm{kg}$ BW Baytril $5 \%$, Bayer AG, Leverkusen, Germany, and $15 \mathrm{mg} / \mathrm{kg}$ BW Betamox LA, Norbrook Laboratories, Newry, UK).

\section{Tissue Preparations}

Immediately after euthanasia of calves, the gastrointestinal tract was removed and flushed with chilled PBS (per liter: $8 \mathrm{~g}$ of $\mathrm{NaCl}, 200 \mathrm{mg}$ of $\mathrm{KCl}, 2.6 \mathrm{~g}$ of $\mathrm{Na}_{2} \mathrm{HPO}_{4}-7 \mathrm{H}_{2} \mathrm{O}$, and $240 \mathrm{mg}$ of $\mathrm{KH}_{2} \mathrm{PO}_{4}, \mathrm{pH}=7.4$ ) and then placed into ice-cold diethyl pyrocarbonatetreated $\mathrm{NaCl}(154 \mathrm{mM})$.

Study 1. Pieces of whole gastrointestinal tract walls (mucosa, submucosa, including muscularis layer and serosa) of esophagus, rumen, fundus, pylorus, duodenum, jejunum, ileum, and colon of a calf were removed, shock-frozen in liquid nitrogen, and stored at $-80^{\circ} \mathrm{C}$ until used for the determination of lactase mRNA levels.

Study 2. Segments of jejunum and ileum were opened longitudinally and were flattened on glass slides, serosal side down, before being frozen in liquid nitrogen. Frozen tissue pieces of $5 \times 5 \mathrm{~mm}^{2}$ were covered with a supporting medium (O.C.T. compound, Tissue-Tek, Zoeterwoude, The Netherlands) and were again placed in liquid nitrogen and then transferred onto a flat supporting surface of $1 \%$ agar within the cryostat at a temperature of $-20^{\circ} \mathrm{C}$, as decribed by Goda et al. (1983). The gut pieces were cut transversely (starting with the villus tips and moving toward serosal side) into slices of $10 \mu \mathrm{m}$ for later determination of mRNA levels of lactase in the different intestinal layers. Fifteen consecutive and morphologically similar slices of $10 \mu \mathrm{m}$ each were collected as fractions consisting mainly of upper parts of villi, crypts, and lamina propria (LP; containing mainly Peyer's patches $[\mathbf{P P}]$ ). Twelve slices of each layer were stored at $-80^{\circ} \mathrm{C}$ for total RNA extraction. To confirm the histological homology of the fraction, the first and last slices of each fraction were stained with hematoxylin and eosin and evaluated microscopically.

\section{Cell Proliferation and Histology}

The slices before the last cut of villus, crypt, and LP layers (containing mainly PP) were assayed for BrdU incorporation to label proliferating cells that were expected to be mainly present in crypt cells (Blättler et al., 2001) and lymphocytes of PP (David et al., 2003). 
Pictures were randomly made through a microscope with a digital camera (AxioCam HR with the software Axio Vision v3.1; Carl Zeiss Vision GmbH, MunichHallbergmoos, Germany).

The presence of typical morphological structures for villus tips, crypts, and $\mathrm{PP}$ was quantitatively evaluated on a computer screen by the grid method in 8 randomly chosen areas of $4 \times 4 \mathrm{~cm}$ (where $1 \mathrm{~cm}$ corresponded to $40 \mu \mathrm{m}$ of the original tissue) using the CorelDraw Photoshop program (CorelDraw 9, Version 9.337, Corel Corporation, Ottawa, Ontario, Canada).

\section{RNA Extraction and cDNA Production}

Total RNA was extracted either from $100 \mathrm{mg}$ of whole gut walls (study 1) or from the combined 12 microtome sections (study 2) of layers consisting mainly of villus tips, crypts, or LP (with PP), using 1 or $0.5 \mathrm{~mL}$ of Trizol as described previously (Ontsouka et al., 2004). The concentration of recovered RNA was measured at an optical density of $260 \mathrm{~nm}$. The quality of RNA was acceptable if the ratio of optical density at 260 to that at 280 was $>1.9$. One microgram of total RNA was reverse transcribed into cDNA using 100 pmol of random hexamer primer as described previously (Ontsouka et al., 2004).

\section{Primer Design and Testing}

The primers for the amplification of the bovine lactase mRNA were designed in the highly conserved regions with $100 \%$ identity based on multiple species (human, rabbit, rat), clustal alignment (www.pasteur.fr), and spanned exons 10 and 11 (Figure 1). The available cDNA sequences were downloaded at http:// www.ncbi.nlm.nih.gov/Entrez/index.html. The GenBank accession numbers were XM_222628 (rat), X07994 (human), and X07995 (rabbit). The primers were designed and tested for self-priming and melting temperature. The sequences of the primers used and their localization in clustal alignment were as follows. Forward primer: 5'-TGGAGAGCAGATGGCAAAGG$3^{\prime}$, i.e., $5^{\prime}$-end (= nucleotide 4186$)$ and $3^{\prime}$-end (= nucleotide 4205); Reverse primer: 5'-CAGCCTCTGGAAGAGCACCTC-3', i.e., 5'- end (= nucleotide 4578) and $3^{\prime}$-end (= nucleotide 4568 ). The PCR product length was $393 \mathrm{bp}$.

The specificity of the PCR product was verified by gel electrophoresis. In addition, the PCR amplicons were sequenced in both directions at the Institute of Veterinary Bacteriology, Vetsuisse Faculty, University of Berne, Switzerland, using the primers that were used for cDNA amplification. Comparison between the sequenced PCR product and the corresponding published coding human, rabbit, and rat sequences was done by clustal alignment at www.pasteur.fr.

\section{Quantification by RT-PCR}

Polymerase chain reactions were performed with LightCycler (Roche Applied Science, Rotkreuz, Switzerland) using $25 \mathrm{ng}$ of reverse transcribed total RNA. Reaction components for PCR mastermix were as described previously (Ontsouka et al., 2004). The following RT-PCR conditions were used for the amplification: denaturation program $\left(95^{\circ} \mathrm{C}\right.$ for $\left.10 \mathrm{~min}\right)$, a 3 segment amplification and quantification program repeated 40 times (denaturation at $95^{\circ} \mathrm{C}$ for $15 \mathrm{~s}$, annealing at $55^{\circ} \mathrm{C}$ for $10 \mathrm{~s}$, elongation and single fluorescence acquisition at $72^{\circ} \mathrm{C}$ for $20 \mathrm{~s}$ ), melting curve program $\left(60^{\circ} \mathrm{C}\right.$ to $99^{\circ} \mathrm{C}$ with a heating rate of $0.1^{\circ} \mathrm{C} / \mathrm{s}$ and continuous fluorescence measurements), and cooling down to $40^{\circ} \mathrm{C}$.

$\beta$-Actin, glyceraldehyde-3-phosphate dehydrogenase (GAPDH), ubiquitin, and 18S were used as control genes (housekeeping genes; HKG). The sequences of primers used for amplification of HKG were from other studies (Inderwies et al., 2003; Reist et al., 2003).

\section{PCR Efficiency, Sensitivity, and Reproducibility}

The sensitivity of the RT-PCR assay for the quantification of lactase was determined during 3 repeated PCR runs using different starting amounts of reverse transcribed RNA. The PCR efficiency (E) was calculated based on the slope calculated by LightCycler software 3.3 (Roche Applied Science, Rotkreuz, Switzerland) using the equation $\mathrm{E}=10[-1 /$ slope $]$. To determine the precision and reproducibility of the assay, the intra- and interassay coefficients variations were determined within one PCR run using 5 repeats, and during 5 different PCR runs, respectively.

\section{Mathematical and Statistical Analyses}

The mRNA expression of lactase and of HKG was evaluated by amplification curve analysis of the LightCycler real-time RT-PCR. The DNA binding dye SYBR Green I incorporated into double-stranded DNA during PCR amplification emits fluorescence of increasing intensity with each cycle number. The exponential phase of the PCR begins when the fluorescence signal from the accumulated PCR product is greater than the background fluorescence. To exclude noninformative fluorescence background points, a fixed fluorescence threshold line is set to the exponential por- 


\begin{tabular}{|c|c|}
\hline $\begin{array}{l}\text { bovine } \\
\text { rat } \\
\text { human } \\
\text { rabbit }\end{array}$ & for $(4186-4205)$-ACTCAGTATCTGGGACACGTTTTCTCACACACCCCTGAAGG- \\
\hline $\begin{array}{l}\text { bovine } \\
\text { rat } \\
\text { human } \\
\text { rabbit }\end{array}$ & 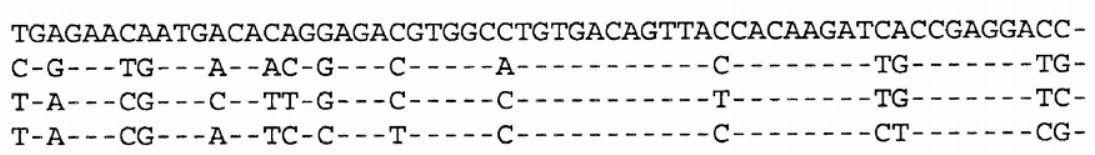 \\
\hline $\begin{array}{l}\text { bovine } \\
\text { rat } \\
\text { human } \\
\text { rabbit }\end{array}$ & 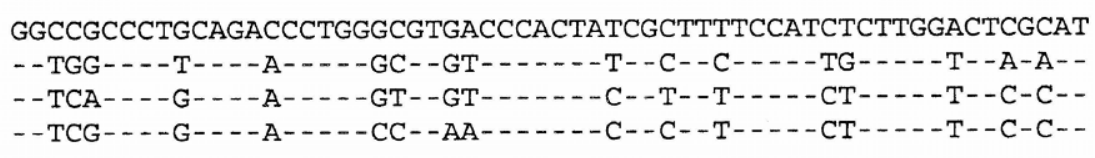 \\
\hline $\begin{array}{l}\text { bovine } \\
\text { rat } \\
\text { human } \\
\text { rabbit }\end{array}$ & 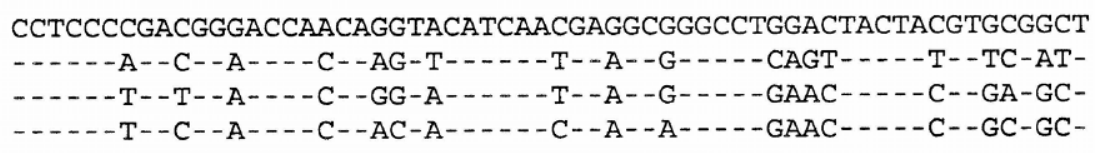 \\
\hline $\begin{array}{l}\text { bovine } \\
\text { rat } \\
\text { human } \\
\text { rabbit }\end{array}$ & 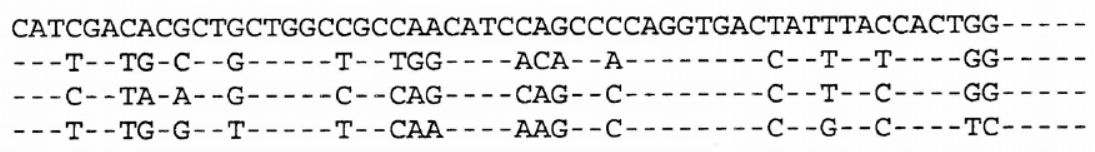 \\
\hline $\begin{array}{l}\text { bovine } \\
\text { rat } \\
\text { human } \\
\text { rabbit }\end{array}$ & 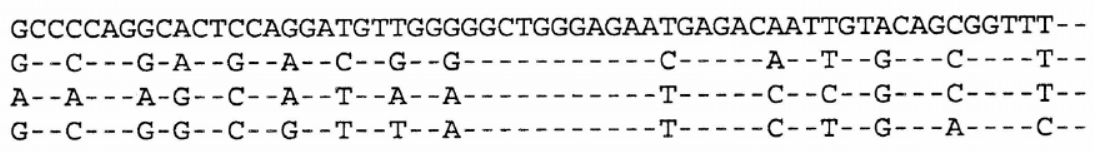 \\
\hline $\begin{array}{l}\text { bovine } \\
\text { rat } \\
\text { human } \\
\text { rabbit }\end{array}$ & 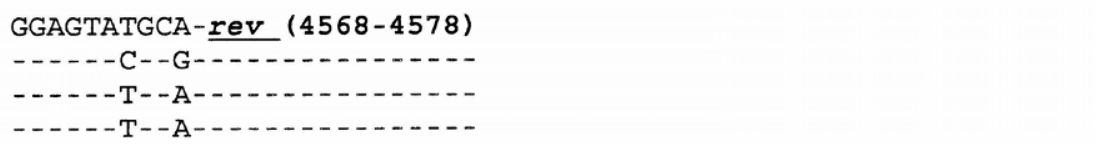 \\
\hline
\end{tabular}

Figure 1. Partial nucleotide sequence of bovine lactase and its alignment to human (GenBank acc. no. X07994), rabbit (GenBank acc. no. X07995), and rat (GenBank acc. no. XM_222628) sequences. The similarity of sequenced-bovine lactase was $87 \%$ with human and rabbit sequences and $82 \%$ with rat sequences. The primers were designed in $100 \%$ identity regions of clustal alignment of these species (rat, rabbit, human). The nucleotide positions of forward primer (for) and reverse primer (rev) in bovine sequence are given in the brackets. Identical positions to the bovine sequence are represented by a dash.

tion of the amplification curve as low as possible without including any background points. The intersection of the threshold line and the amplification curve represents the crossing point (CP) value (Rasmussen, 2001).

The mRNA levels of lactase were related to those of HKG. Basically, HKG expression is constant in a given tissue. This may not be strictly true in rapidly growing animals and, especially, in transition periods, such as during early postnatal periods. If HKG are stable, however, then levels of different HKG should be closely correlated. Because this was the case in our study, we have calculated the mean of CP of GAPDH, ubiquitin, $\beta$-actin, and $18 \mathrm{~S}$ for jejunum and ileum. The $\Delta 1 \mathrm{CP}$ value of HKG represents the difference between the mean CP of the tissue and the individual sample CP. The $\Delta 1 \mathrm{CP}$ corresponds to the number of cycles to be added or subtracted from the individual $\mathrm{CP}$ value to get the virtually constant HKG gene expression in tissues. The lactase $\mathrm{CP}$ value was accordingly normalized in individual samples as $\triangle 2 \mathrm{CP}$. The lactase expression level was calculated as $\left[2^{(-\Delta 2 \mathrm{CP})}\right] \times 100$, where 2 is the efficiency of PCR leading to amplicon duplication at every cycle (Medhurst et al., 2001). Data are presented as means \pm SEM.

Differences among intestinal sites (study 1) and among SI layers (study 2) were tested for significance with the nonparametric Kruskall-Wallis test because 
there was a non-normal distribution of data in some intestinal layers. Effects were considered to be significant if $P<0.05$.

\section{RESULTS AND DISCUSSION}

\section{Primers and PCR Product Specificity for Lactase mRNA}

In this study we developed and validated the quantitative real-time RT-PCR assay for bovine lactase mRNA using the SYBR Green I detection with LightCycler. There have been only few investigations on lactase mRNA expression using RT-PCR technology, and they have all been done in species other than cattle (Boukamel et al., 1995; Lee et al., 2002; Kuokkanen et al., 2003). The present study appears to be the first one that demonstrates a quantitative evaluation (relative to HKG) of lactase mRNA in the bovine species. The specificity of designed primers and of amplified PCR products was demonstrated by melting curve analysis of PCR, by the agarose gel electrophoresis (that showed a single band of expected size, $393 \mathrm{bp}$ ), and by sequencing of amplified PCR products. The sequencing of amplified PCR products in both directions (Figure 1) with the same primers used for each PCR demonstrated acceptable similarities with lactase of humans and rabbits $(87 \%)$ and rats $(82 \%)$. The similarities of published sequences, that is, human compared with rat (79\%), human compared with rabbit (85\%), and rat compared with rabbit (78\%) were in the range of those observed in the present study.

\section{PCR Efficiency, Sensitivity, and Reproducibility of the Assay}

The sensitivity of the quantitative RT-PCR assay for lactase was evaluated using different starting amounts of reverse transcribed RNA that ranged from $2.5 \times 10^{0}$ to $2.5 \times 10^{7} \mathrm{fg}$. The SYBR Green I determination resulted in a reliable and sensitive quantification with high-test linearity $(r \geq 0.99)$ over 6 orders of magnitude. The lactase mRNA could not be amplified when the amount of reverse transcribed RNA was $\leq 2.5 \times$ $10^{1} \mathrm{fg}$. The calculated PCR efficiency (E) of lactase amplification was 1.91 , that is, it was close to 2 . The expression of assay variability was calculated based on the deviation of $\mathrm{CP}$ values from the $\mathrm{CP}$ mean value, and percentage variation was 0.77 and $1.62 \%$, respectively, for intra- and interassay coefficients of variations.

\section{Housekeeping Genes}

Single HKG can, too, be regulated and at least weakly change (Tricarico et al., 2002; Rhoads et al.,
2003). However, in our study the CP values of GAPDH, $18 \mathrm{~S}, \beta$-actin, and ubiquitin in the intestinal fractions were highly correlated because Pearson's coefficients of correlation $(r)$ ranged from 0.87 to $0.99(P<0.05)$, indicating that the $4 \mathrm{HKG}$ were stable and therefore not regulated. If they had been regulated, they would not have been so closely correlated because they stand for such widely different functions that it would be very unlikely that this would occur in a uniform manner. We have chosen to express lactase mRNA levels to mean levels of GAPDH, $18 \mathrm{~S}, \beta$-actin, and ubiquitin, rather than to a single HKG because we reasoned that this would provide an even better basis to express mRNA lactase levels in accordance with Inderwies et al. (2003).

\section{Presence of Lactase mRNA in Total Tissue of Gastrointestinal Tract (Study 1)}

The melting-curve analysis (data not shown) and gel electrophoresis (Figure 2) attested that lactase mRNA could be detected only in total walls (mucosa plus submucosa) of the SI but not in other parts of the gastrointestinal tract (esophagus, rumen, fundus, pylorus, colon), as expected. The same pattern of the presence and absence of mRNA for lactase was seen if pools derived from 7 calves of the different gastrointestinal sites were analyzed (data not shown). The expression pattern of lactase mRNA was in line with other studies on mRNA levels in neonatal rats (Estrada et al., 1996). The data on lactase mRNA expression in the present study correlate with lactase activity patterns of milkfed calves (Le Huërou-Luron et al., 1992).

\section{Expression of Lactase in Mucosal Fractions (Study 2)}

Study 2 was designed to investigate the localization of lactase mRNA within different layers of the jejunum and ileum. To address this question, we have fractionized jejunum and ileum that exhibited high and low abundance of lactase mRNA, as shown in Figure 3. The fractionation of ileum was of interest because of the presence of $\mathrm{PP}$, that in rabbits have been reported to regulate epithelial gene expression, and thus possibly also lactase mRNA (Savidge et al., 1994). Based on BrdU incorporation, proliferating crypt cells could be clearly differentiated from nonproliferating mature enterocytes, especially on tips of villi, and high proliferation rates in PP fractions could be labeled, too, as shown in previous studies (David et al., 2003; Norrman et al., 2003). The histological evaluation (grid method) and immunohistological evaluation (BrdU incorporation in proliferating cells) of slides (Table 1) showed 


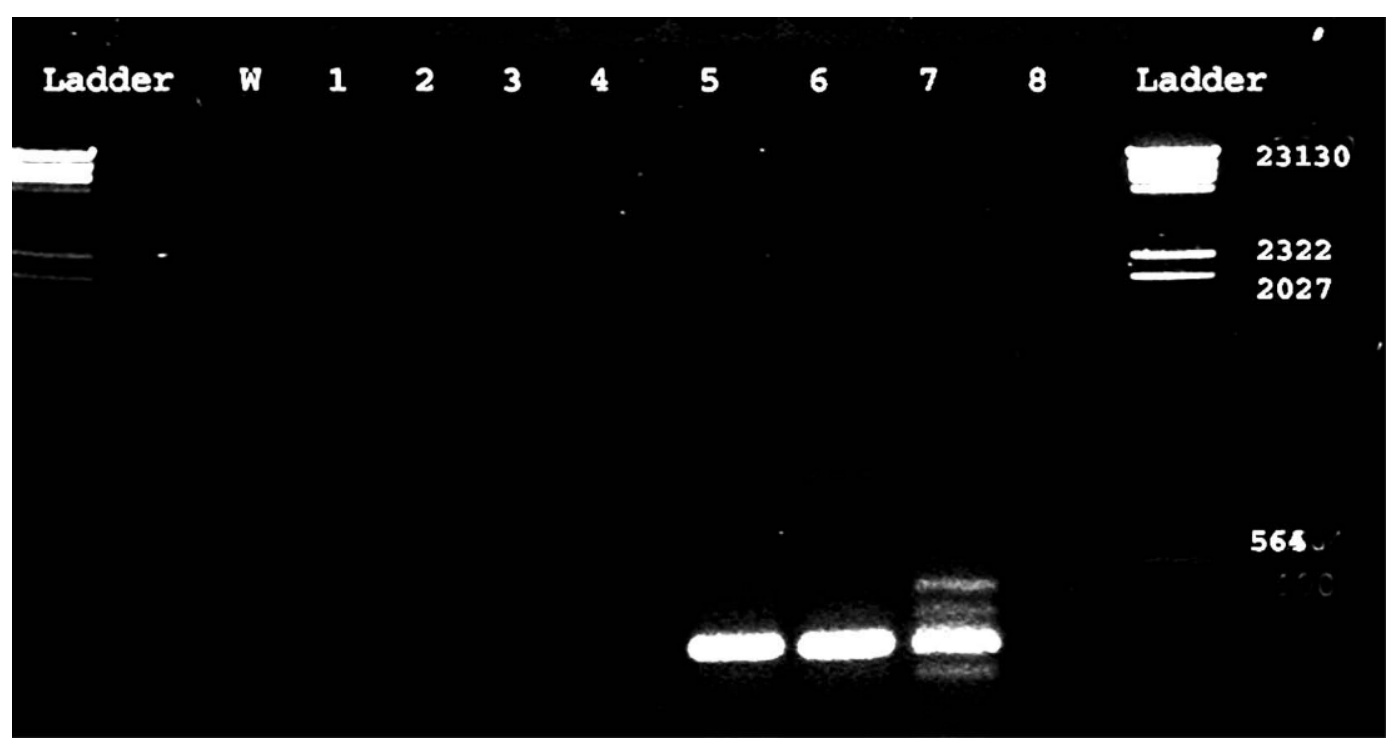

Figure 2. Gel electrophoresis in 1.5\% agarose of RT-PCR products of bovine lactase mRNA in total wall (mucosa plus submucosa) of the gastrointestinal tract of calves. cDNA was prepared from total RNA extracted from esophagus (1), rumen (2), fundus (3), pylorus (4), duodenum (5), jejunum (6), ileum (7), and colon (8). W = negative control (water); L = DNA molecular weight marker Lambda II (Roche), digested with Hind III. Numbers on right indicate number of bp.

that villus and LP fractions (with PP) were very pure and that the crypt fractions were relatively pure because they consisted mainly (up to 92 and $69 \%$ in jejunum and ileum, respectively) of crypts.

As shown in Table 1, in jejunum, the mRNA levels of lactase were higher $(P<0.05)$ in villus than in crypt fractions. Lactase mRNA was also detected in fractionized villus and crypt fractions of the ileum (Figure 3). However, based on the melting curve analysis (data not shown), the lactase signal in the crypt fraction was weak and subsequently may be the reason why lactase cDNA could not be visualized on the $1.5 \%$ agarose gel
(Figure 3). Lactase mRNA levels were numerically, but not significantly, higher $(P=0.42)$ in villus than in crypt fractions (Table 1). A similar distribution of lactase mRNA distribution was found in other species (Duluc et al., 1993; Hansen et al., 1994; Goda et al., 1999; Fan et al., 2001). The high lactase mRNA expression is an indicator of maturation of villus epithelia, especially in the proximal SI. The absence of lactase mRNA in the LP fraction containing mainly PP (Figure 3 ) indicates that the lactase gene is exclusively expressed in the epithelial layer of the intestinal mucosa (Goda et al., 1999).

Table 1. Relative distribution of typical morphological structures of villus tip and crypt fractions of the jejunum and of villus tips, crypts, and lamina propria with Peyer's patches (PP) fractions of the ileum based on histomorphometry, BrdU-labeling, and lactase mRNA levels measured by real-time reverse transcriptionPCR.

\begin{tabular}{|c|c|c|c|c|c|}
\hline \multirow[b]{2}{*}{ Intestine } & \multirow[b]{2}{*}{ Fraction } & \multirow[b]{2}{*}{$\begin{array}{l}\text { Lactase mRNA }{ }^{1} \\
\left(\times 10^{-8} \text { percentage of } \mathrm{HKG}\right)\end{array}$} & \multicolumn{3}{|c|}{ Typical structure identifying for } \\
\hline & & & $\begin{array}{l}\text { Villus } \\
\text { tips }\end{array}$ & Crypts & $\begin{array}{l}\text { Lamina } \\
\text { propria } \\
\text { with PP }\end{array}$ \\
\hline \multirow{3}{*}{ Jejunum } & Villus & $50.5 \pm 21^{\mathrm{a}}$ & $100 \%$ & 0 & 0 \\
\hline & Crypt & $3.74 \pm 2.4^{\mathrm{b}}$ & $8 \%$ & $92 \%$ & 0 \\
\hline & Lamina propria & $\mathrm{ND}^{2}$ & 0 & 0 & 0 \\
\hline \multirow{3}{*}{ Ileum } & Villus & $6.88 \pm 4.69$ & $100 \%$ & 0 & 0 \\
\hline & Crypt & $3.10 \pm 1.8$ & $31 \%$ & $69 \%$ & 0 \\
\hline & Lamina propria & ND & $0 \%$ & $0 \%$ & $100 \%$ \\
\hline
\end{tabular}

\footnotetext{
${ }^{\mathrm{a}, \mathrm{b}}$ Means with different superscript letters are different $(P<0.05)$ villus and crypt fractions.

${ }^{1}$ Lactase levels (means $\pm \mathrm{SEM}, \mathrm{n}=7$ ) are expressed as percentage expression relative to the mean levels of ubiquitin, GAPDH, $\beta$-actin, and 18S.

${ }^{2} \mathrm{ND}=$ Not detected.
} 


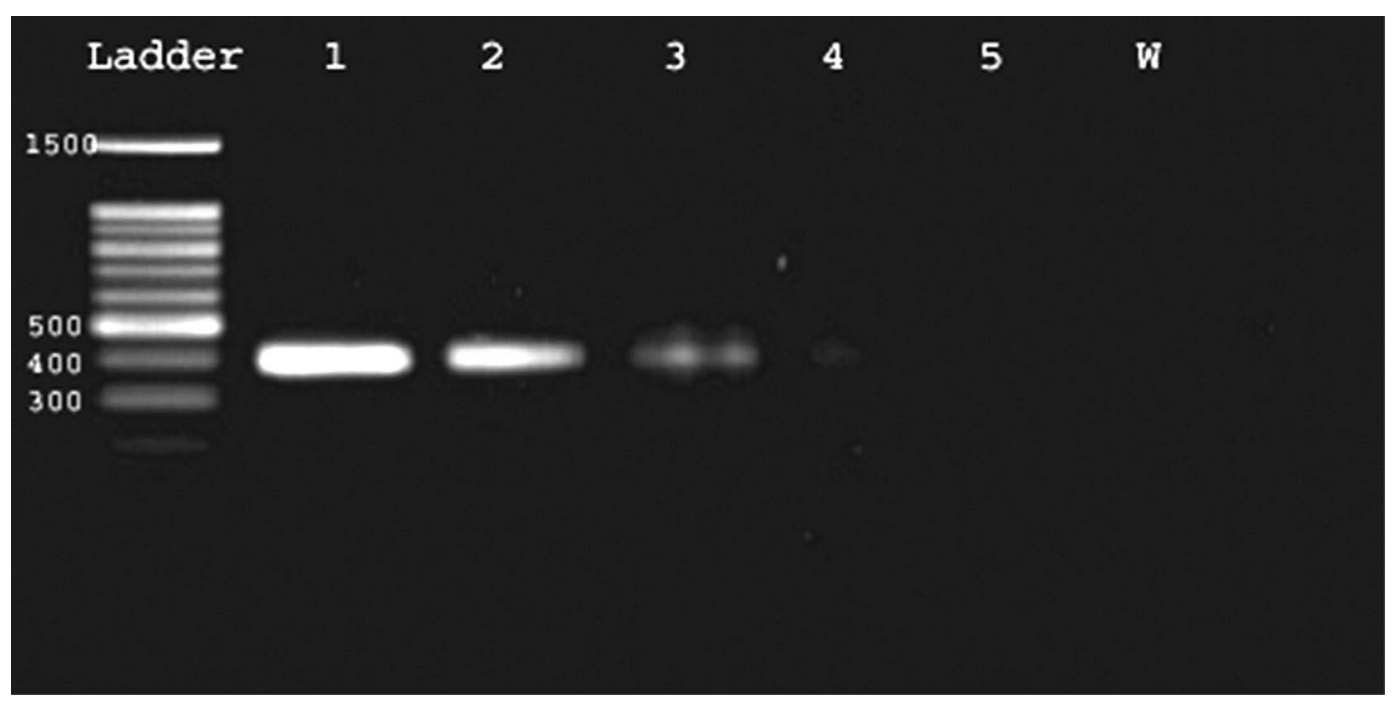

Figure 3. Gel electrophoresis in 1.5\% agarose of RT-PCR products of bovine lactase mRNA in jejunal and ileal mucosal and submucosal fractions. cDNA was prepared from total RNA extracted from fractions mainly of upper parts of villi of jejunum (1), of crypts of jejunum (2), of upper parts of villi of ileum (3), of crypts of ileum (4), and lamina propria containing mainly Peyer's patches (5). W = negative control (water); $\mathrm{L}=100 \mathrm{bp}$ DNA ladder. Numbers on left indicate numbers of bp.

\section{CONCLUSIONS}

The present study provides a quantitative RT-PCR assay for lactase mRNA in the bovine species. The assay will help to study better functional changes of the SI epithelium under normal and pathological conditions, such as in situations characterized by maldigestion, malabsorption, and diarrhea due to intestinal epithelial damages and impaired functions. Such an assay could be applied if analyses of lactase activity are not possible, as is the case when very low amounts of tissues are available, as in the actual study when tissue fractions are to be analyzed.

\section{ACKNOWLEDGMENTS}

We thank M. Pfaffl, Technical University of Munich, Germany, for advice in the design of the primer, and P. Kuhnert, Institute of Veterinary Bacteriology, University of Berne, Switzerland, for support in cDNA sequence analyses.

\section{REFERENCES}

Bittrich, S., C. Philipona, H. M. Hammon, V. Romé, P. Guilloteau, and J. W. Blum. 2004. Preterm as compared with full-term neonatal calves are characterized by morphological and functional immaturity of the small intestine. J. Dairy Sci. 87:1786-1795.

Blättler, U., H. M. Hammon, C. Morel, C. Philipona, A. Rauprich, V. Romé, I. Le-Huërou-Luron, P. Guilloteau, and J. W. Blum. 2001. Feeding colostrum, its composition and feeding duration variably modify proliferation and morphology of the intestine and digestive enzyme activities of neonatal calves. J. Nutr. 131:1256-1263.
Boukamel, R., P. Neuville, and J. N. Freund. 1995. Activity of the rat lactase gene promoter in transfected human colon cancer cells. C. R. Acad. Sci. III 318:1133-1140.

Buller, H. A., M. J. Kothe, D. A. Goldman, S. A. Grubman, W. V. Sasak, P. T. Matsudaira, R. K. Montgomery, and R. J. Grand. 1990. Coordinate expression of lactase-phlorizin hydrolase mRNA and enzyme levels in rat intestine during development. J. Biol. Chem. 265:6978-6983.

David, C. W., J. Norrman, H. M. Hammon, W. C. Davis, and J. W. Blum. 2003. Cell proliferation, apoptosis, and B- and T-lymphocytes in Peyer's patches of the ileum, in thymus and in lymph nodes of preterm calves, and in full-term calves at birth and on day 5 of life. J. Dairy Sci. 86:3321-3329.

Dudley, M. A., D. G. Burrin, A. Quaroni, J. Rosenberger, G. Cook, B. L. Nichols, and P. J. Reeds. 1996. Lactase phlorizin hydrolase turnover in vivo in water-fed and colostrum-fed newborn pigs. Biochem. J. 320:735-743.

Dudley, M. A., L. J. Wykes, A. W. Dudley, Jr., D. G. Burrin, B. L. Nichols, J. Rosenberger, F. Jahoor, W. C. Heird, and P. J. Reeds. 1998. Parenteral nutrition selectively decreases protein synthesis in the small intestine. Am. J. Physiol. 274:G131-G137.

Duluc, I., B. Jost, and J. N. Freund. 1993. Multiple levels of control of the stage- and region-specific expression of rat intestinal lactase. J. Cell Biol. 123:1577-1586.

Estrada, G., S. D. Krasinski, R. K. Montgomery, R. J. Grand, J. Garcia-Valero, and M. D. Lopez-Tejero. 1996. Quantitative analysis of lactase-phlorizin hydrolase expression in the absorptive enterocytes of newborn rat small intestine. J. Cell. Physiol. 167:341-348.

Fan, M. Z., B. Stoll, R. Jiang, and D. G. Burrin. 2001. Enterocyte digestive enzyme activity along villus-crypt and longitudinal axes in the neonatal pig small intestine. J. Anim. Sci. 79:371381.

Freund, J. N., B. Jost, I. Duluc, and G. Morel. 1995. Ultrastructural study of intestinal lactase gene expression. Biol. Cell. 83(23):211-217.

Goda, T., K. Yamada, S. Bustamante, and O. Koldovsky. 1983. Dietary-induced rapid decrease of microvillar carbohydrase activity in rat jejuno-ileum. Am. J. Physiol. 245:G418-G423.

Goda, T., H. Yasutake, T. Tanaka, and S. Takase. 1999. Lactasephlorizin hydrolase and sucrase-isomaltase genes are expressed 
differently along the villus-crypt axis of rat jejunum. J. Nutr. 129:1107-1113.

Hansen, G. H., L. L. Niels-Christiansen, M. D. Poulsen, O. Noren, and H. Sjostrom. 1994. Distribution of three microvillar enzymes along the small intestinal crypt-villus axis. J. Submicrosc. Cytol. Pathol. 26:453-460.

Inderwies, T., M. W. Pfaffl, H. H. Meyer, J. W. Blum, and R. M. Bruckmaier. 2003. Detection and quantification of mRNA expression of alpha- and beta-adrenergic receptor subtypes in the mammary gland of dairy cows. Domest. Anim. Endocrinol. 24:123-135.

Jost, B., I. Duluc, J. L. Vilotte, and J. N. Freund. 1998. Lactase is unchanged in suckling mice fed with lactase-free milk. Gastroenterol. Clin. Biol. 22:863-867.

Kien, C. L., R. E. McClead, and L. Cordero, Jr. 1996. In vivo lactose digestion in preterm infants. Am. J. Clin. Nutr. 64:700-705.

Kuokkanen, M., N. S. Enattah, A. Oksanen, E. Savilahti, A. Oprana, and I. Jarvela. 2003. Transcriptional regulation of the lactasephlorizin hydrolase gene by polymorphisms associated with adult-type hypolactasia. Gut 52:647-652.

Le Huërou-Luron, I., P. Guilloteau, C. Wicker, A. Mouats, J. A. Chayvialle, C. Bernard, J. Burton, R. Toullec, and A. Puigserver. 1992. Activity distribution of seven digestive enzymes along small intestine in calves during development and weaning. Dig. Dis. Sci. 37:40-46.

Lee, S. Y., A. Madan, G. T. Furuta, S. P. Colgan, and E. Sibley. 2002. Lactase gene transcription is activated in response to hypoxia in intestinal epithelial cells. Mol. Genet. Metab. 75:65-69.

Medhurst, A. D., F. Lezoualch, R. Fischmeister, D. N. Middlemiss, and G. J. Sanger. 2001. Quantitative mRNA analysis of five Cterminal splice variants of the human 5-HT4 receptor in the central nervous system by TaqMan real-time RT-PCR. Brain Res. Mol. Brain Res. 90:125-134.

Norrman, J., C. W. David, S. N. Sauter, H. M. Hammon, and J. W. Blum. 2003. Effects of dexamethasone on lymphoid tissue in the gut and thymus of neonatal calves fed with colostrum or milk replacer. J. Anim. Sci. 81:2322-2332.

Ontsouka, C. E., S. N. Sauter, H. M. Hammon, and J. W. Blum. 2004. Effects of colostrum feeding and dexamethasone treatment on
mRNA levels of insulin-like growth factors (IGF)-I and -II, IGF binding proteins -2 and -3 , and on receptors for growth hormone, IGF-1, IGF-2, and insulin in the gastrointestinal tract of neonatal calves. Domest. Anim. Endocrinol. 26:155-175.

Rasmussen, R. 2001. Quantification on the LightCycler. Pages 2134 in Rapid Cycle Real-time PCR, Methods and Applications. S. Meuer, C. Wittwer, and K. Nakagawara, ed. Springer, Heidelberg, Germany.

Reist, M., M. W. Pfaffl, C. Morel, M. Meylan, G. Hirsbrunner, J. W. Blum, and A. Steiner. 2003. Quantitative mRNA analysis of eight bovine 5-HT receptor subtypes in brain, abomasum, and intestine by real-time RT-PCR. J. Receptor Signal Transd. 23:271-287.

Rhoads, R. P., C. McManaman, K. L. Ingvarsten, and Y. R. Boisclair. 2003. The housekeeping genes GAPDH and cyclopilin are regulated by metabolic state in the liver of dairy cows. J. Dairy Sci. 86:2322-2332.

Sangild, P. T., A. L. Fowden, and J. F. Trahair. 2000. How does the foetal gastrointestinal tract develop in preparation for enteral nutrition after birth? Livest. Prod. Sci. 66:141-150.

Savidge, T. C., M. W. Smith, S. Mayel-Afshar, A. J. Collins, and T. C. Freeman. 1994. Selective regulation of epithelial gene expression in rabbit Peyer's patches tissue. Pflugers Arch. 428:391399

Shulman, R. J., R. J. Schanler, C. Lau, M. Heitkemper, C. N. Ou, and E. O. Smith. 1998. Early feeding, feeding tolerance, and lactase activity in preterm infants. J. Pediatr. 133:645-649.

Tang, M., B. Laarveld, A. G. Van Kessel, D. L. Hamilton, A. Estrada, and J. F. Patience. 1999. Effects of segregated early weaning on postweaning small intestinal development in pigs. J. Anim. Sci. 77:3191-3200.

Tricarico, C., P. Pinzani, S. Bianchi, M. Paglierani, V. Distante, M. Pazzagli, S. A. Bustin, and C. Orlando. 2002. Quantitative realtime reverse transcription polymerase chain reaction: Normalization to rRNA or single housekeeping genes is inappropriate for human tissue biopsies. Anal. Biochem. 309:293-300.

Zhang, H., C. Malo, and R. K. Buddington. 1997. Suckling induces rapid intestinal growth and changes in brush border digestive functions of newborn pigs. J. Nutr. 127:418-426. 